\title{
Relation of Vitamin D Deficiency with Breast Cancer Staging in Patients from INMOL Cancer Hospital
}

${ }^{1}$ Maleeha Tahir Butt, ${ }^{2}$ Mukarma Sajjad, ${ }^{3}$ Tahira Naseem

${ }^{I}$ Department of Biochemistry, ABWA Medical College, Faisalabad

${ }^{2}$ Punjab Rangers Teaching Hospital, Lahore

${ }^{3}$ Department of Biochemistry \& Chemical Pathology, Shaikh Zayed Medical Complex, Lahore

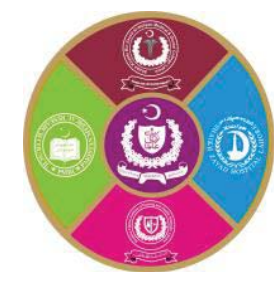

\begin{abstract}
Introduction: Vitamin D deficiency can be critical and is reported to be as one of the factors for development and progression of breast carcinoma. Aims \& Objectives: To measure and compare 25(OH)D (calcidiol) levels in healthy females and in breast carcinoma patients in four different stages. Place and duration of study: This cross sectional study and research was conducted in Shaikh Zayed Medical Complex in the Department of Biochemistry and Chemical Pathology from Jan 2018 to Jan 2019. The patients were selected from INMOL Cancer Hospital, Lahore. Material \& Methods: The study was carried out on 39 healthy females (controls) and 156 newly diagnosed cases of carcinoma breast from stage I to IV, 39 patients of each stage. $25(\mathrm{OH}) \mathrm{D}$ was determined in blood samples of patients by ADVIA Centaur (XP) immunoassay system. Results: In this study the mean 25(OH)D level of healthy females with mean age of $41.7 \pm 15.8$ years, was $25.1 \pm 5.5 \mathrm{ng} / \mathrm{ml} .25(\mathrm{OH}) \mathrm{D}$ level of breast cancer patients was found to be decreasing with stage progression. For the stage I the average 25(OH)D level was $12.31 \mathrm{ng} / \mathrm{ml}$, stage II was $9 \mathrm{ng} / \mathrm{ml}$, stage III was $8.3 \mathrm{ng} / \mathrm{ml}$ and stage IV was $8.4 \mathrm{ng} / \mathrm{ml}$. Conclusion: It was found that healthy group of females had higher values of serum vitamin D levels as compared to breast carcinoma patients. Low concentration of serum vitamin D may contribute to the progression of stage of breast carcinoma.
\end{abstract}

Key words: Vitamin D level, Breast Cancer Staging

\section{INTRODUCTION}

$\mathrm{V}$ itamin $\mathrm{D}$ in its active form $1,25(\mathrm{OH}) \mathrm{D}$ (calcitriol) has effect on various tissues via the vitamin D receptors. ${ }^{1}$ Different types of cancer and chronic diseases are associated with Polymorphisms of the Vitamin D Receptor gene. ${ }^{2}$ Serum 25(OH)D is the best indicator of vitamin D status of the body due to its long half life. ${ }^{3}$ The recommended daily allowance for vitamin $\mathrm{D}$ is 400 to $600 \mathrm{IU}$ international Unit (10-20ug) ${ }^{4}$ Normal concentration of $25(\mathrm{OH}) \mathrm{D}$ is 30 to $50 \mathrm{ng} / \mathrm{ml}$. Deficiency of $25(\mathrm{OH}) \mathrm{D}$ is said to occur when level is $<20 \mathrm{ng} / \mathrm{ml}$ and a vitamin $\mathrm{D}$ insufficiency is said to be presentwhen the level is between 21 and $29 \mathrm{ng} / \mathrm{ml}^{.}{ }^{5}$

Lack of intake of natural foods like egg, fish and cheese shows association with vitamin D deficiency. ${ }^{6}$ A study has revealed correlation between vitamin $\mathrm{D}$ deficiency and cultural and racial variations. ${ }^{7}$ About 70 to $97 \%$ of population in Pakistan has been reported to have Deficiency of Vitamin D, which is more commonly found in urban population. ${ }^{8}$ Deficiency of $25(\mathrm{OH}) \mathrm{D}$ impairs cell proliferation, differentiation, apoptosis and angiogenesis which results in increased cellular growth, neo-angiogensis and cancer development. ${ }^{9}$ Tumor growth can be stimulated by certain receptors within the body, e.g. Estrogen, Progesterone, human epidermal growth hormone receptor (HER2). ${ }^{10}$ Another essential function of 25(hydroxy) vitamin D in conjunction with Vitamin D Receptors (VDR) is its role in innate and adaptive immune system that effects a multitude of biological processes in cell including its influence on the expression of oncogenes and tumor suppressor genes. ${ }^{11}$

25-hydoxy vitamin D combined with binding proteins (S100 and Gc) helps to enhance the immune system and hence lower the chances of cancer. Gc-MAF (macrophage activating factor) is very helpful protein when combined with vitamin D for the remedy of Breast carcinoma. ${ }^{12}$ One of the anti-neoplastic functions of $25(\mathrm{OH}) \mathrm{D}$ is reduction of estrogen receptors through estrogen pathway which means it actually prevents growth of cancer cells by 
inducing cell apoptosis. ${ }^{13}$ Vitamin $\mathrm{D}$ receptors present in mammary gland weaken up in cancer patients due to the dysregulation of metabolism and signaling and this prevents Vitamin $\mathrm{D}$ from performing its anti-tumorigenic effects against cancer. ${ }^{14}$ Recent study from Korea suggested that most of luminal and triple negative breast carcinoma patients had vitamin D deficiency. ${ }^{15}$ Mutation in oncogenes and tumor suppressor genes is the major risk factor in developing breast cancer. ${ }^{16}$

Breast cancer is a major leading cause of death all over the world among women and have accounted over millions of deaths. ${ }^{17}$ It is malignant carcinoma that usually first detected by patient herself who notices an abnormality on a self-examination. Improved public awareness and screening methods (i.e. clinical examination and mammography) have helped in early diagnosis, treatment and thus increasing the survival rates in breast cancer patients. ${ }^{18}$ In Pakistan it is more common in young aged females unlike West where it is normally diagnosed after 60 `s. ${ }^{19}$ The breast cancer in Pakistan is annually rated at 69.1 per 100,000 (agestandardized) as per the records of South Karachi Cancer Registry, it is almost a same figure if compared with Europe and North America. ${ }^{20}$ An estimated 83000 cases are being annually reported in our country and 40,000 deaths are caused by it. One in every 9 Pakistani women develops breast cancer at some stages of her life. This is stated to be as one of the top frequent rates in Asia. According to estimates from International agency of research on cancer (IARC) in 2012, incidence of breast cancer in Pakistani population was $23 \%$ and mortality was $16 \%{ }^{21}$ Breast carcinoma are classified on cell origin (ductal or lobular carcinoma) and cell appearance (well, moderately and poorly differentiated). ${ }^{22}$ American Joint Committee on Cancer (AJCC) staging system has designated staging by TNM Classification into four stages of breast cancer. ${ }^{23}$

Major risk factor of breast carcinoma is the family history in $1^{\text {st }}$ degree relative. ${ }^{24}$ Recurrence and survival rates depend upon the number of lymph nodes involved. ${ }^{25}$ Modifiable risk factors of breast cancer are BMI, physical activity, breast feeding, dietary fat, alcohol and smoking. ${ }^{26}$ In addition to the lymph node status, size and histological grade of tumor, lymphatic / vascular invasion and response to neoadjuvant therapy are necessary for determining the prognosis and recurrence of the disease. ${ }^{27}$ Treatment of breast cancer involves surgery, chemotherapy, radiotherapy, hormone blocking agents and biological agents (monoclonal antibodies) depending on which stage of the cancer is to be treated. ${ }^{28}$

Although some studies have been done where stages of breast cancer were compared with serum vitamin $\mathrm{D}$ levels but there is no evidence regarding relationship of stages and lymph node involvement in carcinoma breast with vitamin D levels. ${ }^{6,29}$ If a relationship between lower serum level of vitamin $D$ and progression of breast cancer is found, then it might be helpful to reduce morbidity and improve prognosis in a newly diagnosed cases of breast cancer by prescribing vitamin $\mathrm{D}$ along with other treatments. Vitamin D intake and sunlight exposure maybe one of the modifiable risk factor for breast cancer progression. ${ }^{30}$

\section{MATERIAL AND METHODS}

The sampling technique was non probability convenient sampling. After approval from institutional review board of FPGMI (F39/NHRC/ADMIN/IRB/265) consent forms were filled and signed by participants of the study. In total 195 respondents (age >15 years) were inducted, which included 39 healthy females and 156 patients who were newly diagnosed with breast cancer presenting for the first time for treatment in INMOL Hospital Lahore, a major cancer treating centre in Pakistan. Breast cancer staging was done by the Pathology Department of INMOL. 156 breast cancer cases were divided into four groups based on the staging (39 in each group). These respondents were non-pregnant females and were not taking any treatment of cancer, vitamin D and calcium supplements. They had no comorbidities like any chronic disease, autoimmune disease, liver disease, bone disease, acute and chronic renal failure. 25hydoxy vitamin $\mathrm{D}$ was determined in blood samples by ADVIA Centaur (XP) immunoassay auto analyzer after quality control test. Vitamin D deficiency was labeled when $25(\mathrm{OH})$ vitamin D level was $<20 \mathrm{ng} / \mathrm{ml}$ on serum analysis. ${ }^{31}$

\section{Statistical analysis:}

The data recorded was analyzed by using SPSS 20.0. Vitamin D level for healthy females and in each stage cases were explained by terms of Mean \pm $\mathrm{SD}$, if normally distributed and median (IQR) otherwise. Comparison of Vitamin D among four stages of disease was made by using One Way ANOVA or Kruskal Wallis depending on normality of data. Vitamin D level was regressed on stage of disease by applying linear regression analysis where $P$ value $\leq 0.05$ which was considered as significant. 


\section{RESULTS}

25-hydoxy vitamin D levels were compared among five groups. It was noted that the healthy female group was having mean vitamin D level of $25.1 \pm 5.5$ $\mathrm{ng} / \mathrm{ml}$. When it came to stage I the mean level was $12.3 \mathrm{ng} / \mathrm{ml}$ with $3 \mathrm{rd}$ quartile of $13.8 \mathrm{ng} / \mathrm{ml}$. For stage II, III and IV more than $75 \%$ cases had vitamin D levels $<10 \mathrm{ng} / \mathrm{ml}$. Difference was of great significance having $\mathrm{p}$-value less than 0.001 . It can also be observed from box plot that stage 1 had relatively lower levels than healthy females and higher than the advance stages. On the other hand it was difficult to note real difference between the stages II to IV. (Table-1, 2 and Fig-1)

\begin{tabular}{|l|c|c|c|c|c|}
\hline & \multicolumn{5}{|c|}{ Vitamin D levels (ng/ml) } \\
\cline { 2 - 6 } & Mean & SD & Q1 & Median & Q3 \\
\hline Healthy Females & 25.1 & 5.5 & 21.2 & 24.2 & 30.4 \\
\hline Stage I & 12.3 & 2.3 & 10.3 & 12.3 & 13.8 \\
\hline Stage II & 9.0 & 1.0 & 8.2 & 9.1 & 9.8 \\
\hline Stage III & 8.3 & 1.6 & 7.0 & 8.5 & 9.3 \\
\hline Stage IV & 8.4 & 2.0 & 7.2 & 8.2 & 9.7 \\
\hline
\end{tabular}

Table-1: Distribution of vitamin D levels for cases by the stage of disease.

\begin{tabular}{|c|c|c|c|c|c|}
\hline \multirow{2}{*}{ Stage } & \multirow[t]{2}{*}{$\mathbf{N}$} & \multirow{2}{*}{$\begin{array}{l}\text { Mean } \\
\text { Rank }\end{array}$} & \multicolumn{3}{|c|}{$\begin{array}{c}\text { Kruskal Wallis } \\
\text { ANOVA }\end{array}$} \\
\hline & & & Chi-sq & Df & p-value \\
\hline Healthy Females & 39 & 175.72 & \multirow{6}{*}{130.86} & \multirow{6}{*}{4} & \multirow{6}{*}{$<0.001$} \\
\hline Stage I & 39 & 125.85 & & & \\
\hline Stage II & 39 & 72.91 & & & \\
\hline Stage III & 39 & 57.09 & & & \\
\hline Stage IV & 39 & 58.44 & & & \\
\hline Total & 195 & & & & \\
\hline
\end{tabular}

Table-2: Comparison of 25(OH) D levels between the

Healthy Female group and four stages of disease.

According to this study the mean rank value of vitamin D level among healthy female group was 175.72, with stage I was 125.85 , with stage II was 72.91 , in stage III was 57.09 and on stage IV was 58.44. According to Kruskal Wallis ANOVA, statistically significant difference was observed between vitamin $\mathrm{D}$ level of respondents among healthy female group and four stages of breast carcinoma. i. e p-value $=<0.001$.

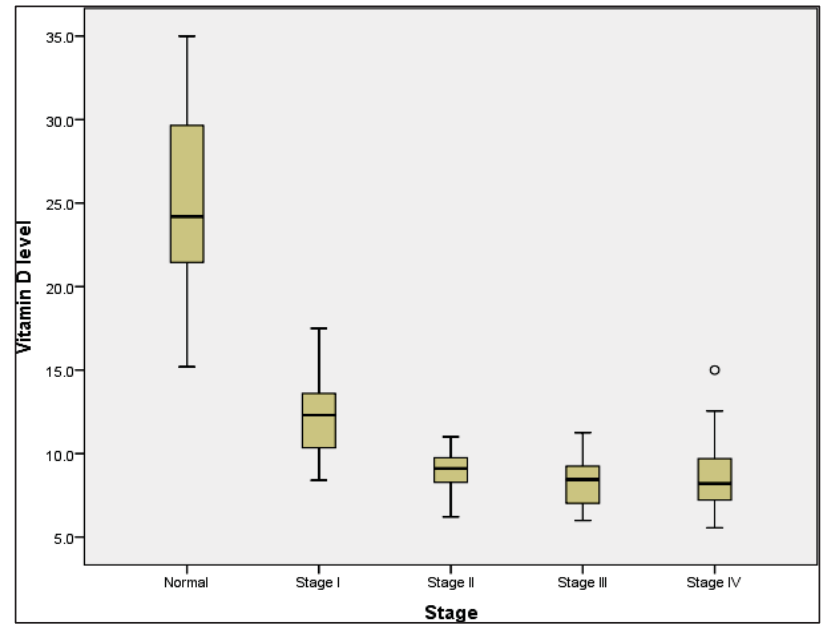

Fig-1: Box plot presenting vitamin D levels for healthy female group and with four stages of disease.

\begin{tabular}{|c|c|c|c|c|}
\hline $\begin{array}{c}\text { Model } \\
\text { summary }\end{array}$ & $\mathbf{R}$ & $\begin{array}{c}\mathbf{R} \\
\text { Square }\end{array}$ & $\begin{array}{c}\text { Adjusted } \\
\text { R Square }\end{array}$ & $\begin{array}{c}\text { Std. } \\
\text { Error } \\
\text { of } \\
\text { Estimate }\end{array}$ \\
\cline { 2 - 5 } & $0.92^{\mathrm{a}}$ & 0.842 & 0.830 & 2.85 \\
\hline
\end{tabular}

a. Predictors: (Constant), Stages of Brest Cancer

\begin{tabular}{|c|c|c|c|c|c|}
\hline \multirow{2}{*}{ Model } & $\begin{array}{c}\text { Unstandardized } \\
\text { Coefficients }\end{array}$ & & \begin{tabular}{|l|} 
Standardized \\
Coefficients \\
\end{tabular} & \multirow{2}{*}{$\mathbf{T}$} & \multirow{2}{*}{ P -value } \\
\hline & B & $\begin{array}{c}\text { Std. } \\
\text { Error }\end{array}$ & Beta & & \\
\hline (Constant) & 23.89 & 5.38 & & 4.44 & $<0.001$ \\
\hline Stage I & -12.31 & 0.72 & -0.71 & -17.08 & $<0.001$ \\
\hline Stage II & -15.34 & 0.75 & -0.89 & -20.53 & $<0.001$ \\
\hline Stage III & -15.68 & 0.75 & -0.92 & -20.88 & $<0.001$ \\
\hline Stage IV & -15.46 & 0.76 & -0.91 & -20.37 & $<0.001$ \\
\hline
\end{tabular}

Table-3: Vitamin D relation with four stages of breast carcinoma by using linear regression analysis

According to the study vitamin D relation with different stages of breast carcinoma was regressed by applying linear regression analysis, difference was found in vitamin $\mathrm{D}$ levels with change in the stage of cancer. For Stage I the average decrease was $12.31 \mathrm{ng} / \mathrm{ml}$ and for other three stages a decrease was just over $15 \mathrm{ng} / \mathrm{ml}$ i.e $\mathrm{P}$ value $<0.001$ (Table-3).

\section{DISCUSSION}

This study represents the comparison of $25(\mathrm{OH}) \mathrm{D}$ levels between the age matched healthy female group and four stages of breast carcinoma patients. 195 respondents were inducted, which included 39 healthy females and 156 breast cancer patients (39 of each stage) before starting treatment.

The mean value of vitamin $\mathrm{D}$ level of the respondents in healthy female group was 
$25.1 \pm 5.5 \mathrm{ng} / \mathrm{ml}$, with disease at stage I was $12.3 \pm 2.3$ $\mathrm{ng} / \mathrm{ml}$, at stage II was $9.0 \pm 1.0 \mathrm{ng} / \mathrm{ml}$, at stage III was $8.3 \pm 1.6 \mathrm{ng} / \mathrm{ml}$ and at stage IV was $8.4 \pm 2.0 . \mathrm{ng} / \mathrm{ml}$ According to Kruskal Wallis ANOVA, statistically significant difference was observed between vitamin D level of respondents among healthy female group and four stages of disease. i.e $\mathrm{p}$ value $=<0.001$. (Table-1 \& 2) The main difference was found in vitamin D levels with change in the stage of cancer. For stage I the average decrease was $12.31 \mathrm{ng} / \mathrm{ml}$ and for other three stages a decrease was just over $15 \mathrm{ng} / \mathrm{ml}$ i.e $\mathrm{P}$ value $<0.001$. (Table- 3 )

Many observational prospective and retrospective studies have been conducted in the past regarding the association between vitamin D and Breast carcinoma which have resulted in inconsistency. This might be due to the factors such as tumor biology and different population. Although the increased research and studies in Europe, America, Japan, France, China and Australia have increased the awareness among women about UVB sun exposure which is source of vitamin D and can help to prevent breast cancer. ${ }^{32}$ In a study of Y Kim et al, inverse associations was found among vitamin D status and cancer prognosis. ${ }^{15}$ In a study at Shaukat Khanum Memorial Cancer Hospital and Research center, Lahore (SKMCH) vitamin D deficiency was found in $99 \%$ of breast cancer patients and $90 \%$ of control group. ${ }^{33}$

It has been reported in a study done in SKMCH in 2012 that the median 25(OH)D level was $9.3 \pm 4.7 \mathrm{ng} / \mathrm{ml}$ among patients of breast cancer which was relatively low as compared to healthy females $(14.9 \pm 10.3 \mathrm{ng} / \mathrm{ml})$. In this study, females at stage I carcinoma had mean vitamin $\mathrm{D}$ level of $12.75 \pm 5.76 \mathrm{ng} / \mathrm{ml}$, females at stage II had $9.18 \pm 5.31 \mathrm{ng} / \mathrm{ml}$, at stage III was $8.49 \pm 3.18 \mathrm{ng} / \mathrm{ml}$, and at stage IV was $9.86 \pm 3.29 \mathrm{ng} / \mathrm{ml}$, but the difference was insignificant $(\mathrm{p}>0.05){ }^{6}$ Another study referred by Arunkumar Karthikayan et al concluded that low level of $25(\mathrm{OH}) \mathrm{D}$ in women was associated with aggressive breast cancer phenotypes. $^{34}$

According to a case control study an inverse relationship existed between breast carcinoma and serum vitamin D level that was taken after breast cancer diagnosis but different results were obtained in a prospective study where measurements were taken long before diagnosis. ${ }^{29} \mathrm{~A}$ case control study held in Dow University Hospital in 2017 revealed that vitamin D levels were lower in breast cancer patients $(85.7 \%)$ as compared to healthy females $(55.8 \%) .{ }^{35}$

A case control study conducted at Agha Khan University Hospital in Karachi, manifested that vitamin D levels in cases was $15.3 \mathrm{ng} / \mathrm{ml}$ and in controls wad $16.7 \mathrm{ng} / \mathrm{ml}$. A study population of $60.2 \%$ showed vitamin D deficiency and severe vitamin D deficiency $(<12 \mathrm{ng} / \mathrm{ml})$ in $34.8 \%$ of Pakistani women. On the other hand the supplementation of vitamin D was associated with decreased risk of breast carcinoma. ${ }^{36} \mathrm{~A}$ case control study on 200 age matched healthy females and newly diagnosed invasive breast cancer patients concluded that increasing 1 unit serum $25(\mathrm{OH}) \mathrm{D}$, decreases the risk of breast carcinoma by $13.8 \%{ }^{37}$

Concurrence of data from our research with all these studies strongly suggest that the therapeutic use of vitamin $\mathrm{D}$ in breast cancer patients may aid in slow progression of the tumor. It is very important to decrease the incidence of breast cancer by increasing awareness about effects of vitamin D deficiency as well as there is urgent need for intensive and comprehensive breast cancer education that helps in early presentation to the hospital and detection of the disease.

\section{CONCLUSION}

It may be concluded from this study that lower level of serum 25(OH)D were found in females with breast cancer as compared to healthy females. These levels were further found to be lower in advanced stages of breast cancer as compared to stage 1 . Therefore in Pakistani women low concentration of serum vitamin D may contribute to the progression of breast carcinoma.

Hence Vitamin D level should be measured during treatment or follow up so that there is no further breast cancer stage progression. This can help to reduce morbidity and mortality by correcting the deficient levels of vitamin $\mathrm{D}$. Therefore by vitamin $\mathrm{D}$ supplementation along with decreasing modifiable risk factors, incidence of breast carcinoma can be reduced.

\section{Limitations and future research:}

There were some key limitations in this study in terms of financial restriction that didn't allow us to study larger group of samples. Patients at Stage I and II should be followed to see whether stage progression occur or not with low vitamin $\mathrm{D}$ status. This study should be conducted as multicenter research study and teams should be appointed with larger sample size to correlate vitamins D dosage with progression of breast carcinoma. More over the effect of pharmacological agents, used for breast cancer treatment, on vitamin $\mathrm{D}$ levels should be studied. 


\section{REFERENCES}

1. D. Feldman, A.V. Krishnan, S. Swami, E. Giovannucci, B.J. Feldman The role of vitamin $\mathrm{D}$ in reducing cancer risk and progression, Nat Rev Cancer, 2014(14): 342-57.

2. Jbjn Lu D, Jing L, Zhang S. Vitamin D Receptor Polymorphism and Breast Cancer Risk: A Meta-Analysis. Medicine (Baltimore). 2016; 95(18):e3535.

3. Kevin D Cashman, Ellen GHM van den Heuvel, Ruud JW Schoemaker, et al. 25Hydroxyvitamin D as a Biomarker of Vitamin D Status and Its Modeling to Inform Strategies for Prevention of Vitamin D Deficiency within the Population, Advances in Nutrition, 2017(8): 947-57.

4. Ross AC, Manson JE, Abrams SA, et al. The 2011 report on dietary reference intakes for calcium and vitamin D from the Institute of Medicine: what clinicians need to know. J Clin Endocrinol Metab. 2011; 96(1):53-58.

5. Acevedo F, Pérez V, Pérez-Sepúlveda A, Florenzano P, Artigas R, Medina L, Sánchez C. High prevalence of vitamin $\mathrm{D}$ deficiency in women with breast cancer: The first Chilean study. Breast. 2016; 29:39-43.

6. Imtiaz S, Siddiqui N, Raza SA, LoyaA, Muhammad A. vitamin D deficiency in newly diagnosed breast cancer patients. Indian J Endocrinol Metab. 2012; 16(3):409-13.

7. Khan QJ, Kimler BF, Fabian CJ. The relationship between vitamin $\mathrm{D}$ and breast cancer incidence and natural history. Curr Oncol Rep. 2010 Mar; 12(2):136-42.

8. Iqbal R, Khan AH. Possible causes of vitamin D deficiency (VDD) in Pakistani population residing in Pakistan. J Pak Med Assoc. 2010; 60(1):1-2.

9. Wang D, Vélez de-la-Paz OI, Zhai JX, Liu DW. Serum 25-hydroxyvitamin D and breast cancer risk: a meta-analysis of prospective studies. Tumour Biol. 2013; 34(6):3509-17.

10. Johan Staaf, Markus Ringnér, Johan VallonChristersson, et al., Barkardottir, and Åke Borg. Journal of Clinical Oncology 2010 28:11,1813-20

11. Pludowski P, Holick MF, Pilz S, Wagner CL, Hollis BW, Grant WB, et al. Vitamin D effects on musculoskeletal health, immunity, autoimmunity, cardiovascular disease, cancer, fertility, pregnancy, dementia and mortality-a review of recent evidence. Autoimmun Rev. 2013; 12(10):976-89. Epub

12. Thyer L, Ward E, et al. A novel role for a major component of the vitamin D axis: vitamin D binding protein-derived macrophage activating factor induces human breast cancer cell apoptosis through stimulation of macrophages. Nutrients. 2013 Jul 8; 5(7):2577-89.

13. Swami S, Krishnan AV, Wang JY, Jensen K, Horst R, Albertelli MA, et al. Dietary vitamin D3 and 1, 25-dihydroxyvitamin D3 (calcitriol) exhibit equivalent anticancer activity in mouse xenograft models of breast and prostate cancer. Endocrinology. 2012; 153(6):2576-87.

14. Jeon, SM., Shin, EA. Exploring vitamin D metabolism and function in cancer. Exp Mol Med 50, 20(2018).

15. Kim HJ,Lee YM, Ko BS, et al.Vitamin D deficiency is correlated with poor outcomes in patients with luminal-type breast cancer. Ann surg Oncol. 2011; 18(7):1830-6.

16. Muhammad N, Nawaz R, Khan FA, Naeemi H, Rashid MU. Inherited genetic susceptibility to breast cancer in Pakistan. J Cancer Allied Spec. 2018; 4(2).

17. Bray F, Ferlay J, Soerjomataram I, Siegel RL, Torre LA, Jemal A. Global cancer statistics 2018: GLOBOCAN estimates of incidence and mortality worldwide for 36 cancers in 185 countries. CA: a cancer journal for clinicians. 2018; 68(6):394-424.

18. Royce ME, Osman D. Everolimus in the Treatment of Metastatic Breast Cancer. Breast Cancer (Auckl). 2015; 9:73-9.

19. Soomro R, Faridi S, Khurshaidi N, Zahid N, Mamshad I. Age and stage of breast cancer in Pakistan: an experience at a tertiary care center. J Pak Med Assoc. 2018; 68(11): 1682-85.

20. Hafiz Muhammad Asif, et al. "Prevalence, Risk factors and Disease knowledge of Breast Cancer in Pakistan" Asian Pacific journal of cancer prevention, vol 15, 2014: 4411-4416.

21. IARC Working Group on the Evaluation of Carcinogenic Risks to Humans. Biological agents. Volume 100 B. A review of human carcinogens. IARC MonogrEvalCarcinog Risks Hum. 2012; 100(Pt B):1-441.

22. Tsang JYS, Tse GM. Molecular Classification of Breast Cancer. Adv AnatPathol. 2020; 27(1):27-35.

23. Weiss A, Chavez-MacGregor $M$, et al. Validation Study of the American Joint Committee on Cancer Eighth Edition Prognostic Stage Compared with the Anatomic Stage in Breast Cancer. JAMA Oncol. 2018; 4(2): 203-209.

24. Bauer SR, Hankinson SE, Bertone. Johnson ER, Ding EL, Plasma Vitamin D levels, Menopause, and risk of breast cancer: dose. responses meta- 
analysis of prospective studies. Medicine. 2013; 92: 123-131.

25. Asif HM, Sultana S, Akktar N, Jalil Ur Rehman, Riaz Ur Rehman. Prevalence, risk factors and disease knowledge of breast cancer in Pakistan. Asian Pac J cancer Prev 2014; 15 (11): 4411-6.

26. Eliassen AH, Hankinson SE, Rosner B, Holmes MD, Willett WC. Physical activity and risk of breast cancer among postmenopausal women. Archives of internal medicine. 2010; 170(19):1758-64.

27. Janbabai G, Shekarriz R, Hassanzadeh H, Aarabi M, Borhani SS. A survey on the relationship between serum 25-Hydroxy vitamin $\mathrm{D}$ level and tumor characteristics in Oncol Stem Cell Res. 2016; 10:30-36.

28. Wockel A, Albert US, Janni W, Schari A, Kreienberg R, Stuber $\mathrm{T}$. the Screening, Diagnosis, Treatment, and Follow -up of Breast Cancer. DischArztebl int. 2018;115(18):316-23.

29. Yin L, Grandi N, Raum E, Haug U, Arndt V, Brenner H. Meta- analysis: serum vitamin D and breast cancer risk. European Journal of Cancer. 2010; 46(12):2196-205.

30. Basharat, et al. Vitamin D deficiency as a risk factor of breast cancer. Journal of Rawalpindi medical college (JRMC)2014; 18(2):199-01.

31. Siemens ADVIA centaur ex vitamin D total (vitd) assay. Tarrytown, ny, usa: simens healthcare diagnostics; 2013.

32. Engel 1s, satagopan j, sima CS, Orlow 1, mujumdar $u$, coble $j$, et al. sun exposure, vitamin $\mathrm{D}$ receptor genetic variants and list of breast cancer in the agricultural health study. Environ health perspect. 2014; 122:165-171.

33. Imtiaz S, Siddiqui N. Vitamin-D status at breast cancer diagnosis: correlation with social and enviormental factors and dietry intake. Journal of Ayub Medical College Abbottabad. 2014; 26(2):186-90.

34. Karthikayan A, Sureshkumar S, Kadambari D,
Vijayakumar C. Low serum 25-hydroxy vitamin D levels are associated with aggressive breast cancer variants and poor prognostic factors in patients with breast carcinoma. Archives of endocrinology and metabolism.2018;62(4):452-9

35. Shaukat N, Jaleel F, Moosa FA, Qureshi NA. Association between Vitamin D deficiency and Breast Cancer. Pak J Med Sci.2017;33(3):645-49

36. Shamsi U, Khan S, Azam I, Habib Khan, et al. A multicenter case control study of association of vitamin $\mathrm{D}$ with breast cancer among women in Karachi, Pakistan. JCO Global Oncol. 2020; 15(1):873-83.

37. Husain NE, Suliman AA, Abdelrahman I, et al. Serum vitamin D level, sun-exposed area, dietary factors, and physical activity as predictors of invasive breast cancer risk among Sudanese women: A case-control study. J Family Med Prim Care. 2019; 8(5):1706-1714.

\section{The Authors:}

Dr. Maleeha Tahir Butt

Senior Demonstrator,

Department of Biochemistry

ABWA Medical College, Faisalabad.

Dr. Mukarama Sajjad

House Officer,

Punjab Rangers Teaching Hospital, Lahore

Prof. Dr. Tahira Naseem

HOD, Biochemistry and Chemical Pathology,

Shaikh Zayed Medical Complex, Lahore.

\section{Corresponding Author:}

Dr. Maleeha Tahir Butt

Senior Demonstrator,

Department of Biochemistry

ABWA Medical College, Faisalabad.

E-mail: maleehatahirbutt@gmail.com 